Productivity, Efficiency and Economic Growth: East Asia and the Rest of the World Author(s): Gaofeng Han, Kaliappa Kalirajan, Nirvikar Singh

Source: The Journal of Developing Areas, Vol. 37, No. 2 (Spring, 2004), pp. 99-118

Published by: College of Business, Tennessee State University

Stable URL: http://www.jstor.org/stable/4192961

Accessed: 19/04/2010 22:30

Your use of the JSTOR archive indicates your acceptance of JSTOR's Terms and Conditions of Use, available at http://www.jstor.org/page/info/about/policies/terms.jsp. JSTOR's Terms and Conditions of Use provides, in part, that unless you have obtained prior permission, you may not download an entire issue of a journal or multiple copies of articles, and you may use content in the JSTOR archive only for your personal, non-commercial use.

Please contact the publisher regarding any further use of this work. Publisher contact information may be obtained at http://www.jstor.org/action/showPublisher?publisherCode=cbtsu.

Each copy of any part of a JSTOR transmission must contain the same copyright notice that appears on the screen or printed page of such transmission.

JSTOR is a not-for-profit service that helps scholars, researchers, and students discover, use, and build upon a wide range of content in a trusted digital archive. We use information technology and tools to increase productivity and facilitate new forms of scholarship. For more information about JSTOR, please contact support@jstor.org. 


\title{
PRODUCTIVITY, EFFICIENCY AND ECONOMIC GROWTH: EAST ASIA AND THE REST OF THE WORLD
}

\author{
Gaofeng Han \\ University of California, U.S.A. \\ Kaliappa Kalirajan \\ Foundation for Advanced Studies on International Development, Japan \\ Nirvikar Singh \\ University of California, U.S.A.
}

\begin{abstract}
This study compares the sources of growth in East Asia with the rest of the world, using a methodology that allows one to decompose total factor productivity (TFP) growth into technical efficiency changes (catching up) and technological progress. It applies a varying coefficients frontier production function model to aggregate data for the period 1970-1990, for a sample of 45 developed and developing countries. Our results are consistent with the view that East Asiun economies were not outliers in terms of TFP growth. Of the high-performing East Asian economies, our methodology identifies South Korea as having the highest TFP growth, followed by Singapore, Taiwan and Japan. Our methodology also allows us to separately estimate technical efficiency change, which is a component of TFP growth, and we find that, in general, the estimated technical efficiency of the high-performing East Asian economies was not out of line with the rest of the world.
\end{abstract}

JEL Classifications: C21, O30, O47.

Keywords: Total Factor Productivity Growth, Technical Efficiency Change, Technical Progress, Sources of Growth, Varying Coefficients Frontier Production Functions. 
100 Gaofeng Han, Kaliappa Kalirajan, Nirvikar Singh

\section{INTRODUCTION}

Starting from the 1960s several East Asian countries achieved sustained high rates of growth that were unprecedented. This growth experience not only dramatically changed people's lives in those countries, but also raised issues such as what had been the contributing factors, and whether the East Asian experience was replicable. While the East Asian economies, such as Singapore, South Korea, Taiwan and Japan, are a diverse group, economic analysis focuses on sources of growth that are quantifiable and have potentially the same impact across countries. These include the role of factor accumulation and of technological change. While institutional, cultural and political factors are certainly relevant, and have been addressed by economists to the extent that they can be quantified (e.g., Barro and Sala-i-Martin, 1995, Barro,1997), much of the attention has been on the relative roles of increases in the quantities of the basic economic inputs, namely capital and labor, versus changes in the productivity of those inputs.

While some assessments of the "sources of growth" literature (e.g., Felipe, 1999) have questioned this entire approach and its theoretical basis, it remains true that empirical studies have been both numerous and influential. For example, the World Bank (1993) and Hughes (1995) examined the contribution of public policy in economic development; Kim and Lau (1994), Young (1992, 1995) and Krugman (1994) emphasized capital accumulation in the high performing East Asian economies; Sonobe and Otsuka (2001) advanced a hypothesis that capital deepening associated with transformation of industrial structure has been the major factor for sustaining growth for a long period in East Asia; Hayami and Ogasawara (1999) argued that Japan has continued to depend more heavily on physical capital accumulation mainly due to its characteristic of borrowed-technology based economic growth; and Singh and Trieu (1997, 1999) focused more on the role of technological change. Despite many differences in data and analytical methodologies, these and numerous other studies tended to have one common assumption in analyzing the relative role of input accumulation and productivity change: they assumed that production was always on the frontier without any slack in production.

In this paper, we relax this assumption of full technical efficiency, instead allowing for the possibility that an economy may be inside the best practice frontier. This approach is justified by the fact that the production process is not simply an engineering relationship between a set of inputs and observed output, but instead is the result of a series of economic decisions based on various non-price and organizational factors, which influence the method of application of inputs. Hence the relevant economic institutions will also play an important part in an economy's output. Our approach allows us to calculate total factor productivity growth in an alternative manner to most previous studies. More importantly, it allows us to distinguish between changes in technical efficiency (movement towards the frontier) and technological progress (shifting the frontier) in analyzing the sources of growth in East Asia. Making this distinction in a cross-country analysis represents the main contribution of the paper. 
The structure of the paper is as follows. Section 2 provides a brief literature review, focusing on papers that are most relevant to our work. The methodology followed in this paper, as well as the data used, are explained in Section 3. In Section 4, we present the empirical results for our cross-country analysis. Section 5 provides a summary conclusion.

\section{SOURCES OF GROWTH IN EAST ASIA: PREVIOUS STUDIES}

The work closest in spirit to ours is that of Young (1994), Fischer (1993), Marti (1996) and Collins and Bosworth (1997), who all looked at large cross-sections of countries. Young regressed the output growth rate per worker on a constant and the growth of capital per worker for the period 1970-1985 using cross-country data constructed from the Penn World Tables. The capital stock was constructed by the perpetual inventory method with the accumulating investment flows for 1960-1969 as benchmark, and a $6 \%$ depreciation rate. Young's results from this exercise were that, while TFP growth in Hong Kong was relatively high, it was not out of the ordinary in South Korea and Taiwan, and very low in Singapore. Fischer (1993) used the growth accounting method to estimate three sets of TFP growth rates, each with a different weight for labor and capital, on data from the Penn World Tables. He obtained a negative TFP growth rate for Singapore, and fairly low rates of TFP growth for Taiwan. Marti (1996) examined Young's (1994) results with slightly fewer countries but more periods than Young's data set, again using the Penn World Tables. She obtained a positive TFP contribution to the growth rate for Singapore, while her results for other East Asian high performers were roughly consistent with Young's. Using growth accounting, Collins and Bosworth also found rates of TFP growth for East Asian high performers that were not extraordinarily high.

Not all detailed growth accounting exercises agree with the results of crosscountry analyses. Looking at Hong Kong, Singapore, South Korea, and Taiwan, Young (1995) argued that East Asia was not very different from Latin America in its TFP changes. However, Singh and Trieu (1999) showed that this conclusion might be flawed, since it was based on comparing results from different methodologies. Other growth accounting exercises for individual East Asian countries have also given mixed results (Felipe, 1999).

The use of a frontier production function approach to analyze TFP growth in East Asia is more recent than growth accounting estimates. For example, in a widerranging study, Han, Singh and Kalirajan (2001) apply the stochastic production frontier methodology to manufacturing sector data for Hong Kong, Japan, Singapore and South Korea, performing analyses across sectors as well as across countries. They demonstrated that this methodology has facilitated decomposing TFP growth into technical efficiency 
changes and technological progress, and found that input growth has been the major contributor to economic growth in the four economies considered. However, that analysis leaves an unanswered question of how do the East Asian high performers compare to the rest of the world in terms of sources of growth. This paper fills this gap by applying the frontier production analysis to a cross-section of countries that includes most of the East Asian high performers.

\section{METHODOLOGY AND DATA}

A variety of techniques have been used to measure TFP growth (e.g., Fried, Lovell and Schmidt 1993). This study applies a recently developed technique, i.e., the varying coefficient production frontier approach. which isolates catching up to the frontier (technical efficiency improvement) from shifts in the frontier (technical progress) (Kalirajan, Obwona and Zhao, 1996). This approach assumes that an economy obtains its full technical efficiency by following best practice techniques, given the technology. In other words, technical efficiency is determined by the method of application of inputs, regardless of the levels of inputs (that is, scale of operation). This implies that different methods of applying various inputs will influence the output differently, and the slope coefficients will vary from economy to economy. This varying coefficient production frontier approach is an improvement over the conventional constant-slope production frontier approach to measuring technical efficiency (Aigner et al, 1977; Meeusen et al, 1977).

For a given technology, it may be interesting to know whether the gap between "best practice" techniques and realized production methods is diminishing or widening over time. Changes in technical efficiency can be substantial and may outweigh gains from technical progress itself. It is, therefore, important to know how far one is off the production (technology) frontier at any point in time, and how quickly one can reach the frontier. For instance, in the case of economies such as East Asian countries, which borrow technology extensively from abroad, failure to acquire and adapt the new technology to local production environment will result in not operating on the production frontier, but below it without realizing the full potential of the borrowed technology. The movement of the production or technology frontier over time, on the other hand, reflects the success of explicit policies to facilitate the acquisition of foreign technology. Similarly, changes in technical efficiency over time and across individual countries will indicate the level of success of a number of important dimensions of industrial policies. Technical efficiency and technical progress are examined for a given level of inputs.

The technological change component of productivity growth captures shifts in the frontier technology and can be interpreted as providing a measure of innovation. This decomposition of total factor productivity growth into technical efficiency improvement (catching-up) and technological change is, therefore, useful in distinguishing innovation or adoption of new technology by "best practice" firms from the diffusion of technology. Co-existence of a high rate of technological progress and a low rate of change in technical efficiency may reflect the failures in achieving technological mastery or diffusion. 
Productivity, Efficiency and Economic Growth 103

The Varying Coefficients Stochastic Frontier Model

Assuming a Cobb Douglas production technology, the varying coefficients production frontier for the $\mathrm{t}^{\text {th }}$ period can be written as follows:

$$
\begin{aligned}
& \ln Y_{i t}=\alpha_{1 i}+\sum_{k=2}^{K} \beta_{k i} \ln X_{k u} \\
& i=1, \ldots, N .
\end{aligned}
$$

where $\alpha_{1 i}=\bar{\alpha}_{1}+u_{1 i} ;$ and $\mathrm{Y}_{\mathrm{it}}$ is the output level of the $\mathrm{i}^{\text {th }}$ economy in period $\mathrm{t}$; $\mathrm{X}_{\mathrm{kit}}$ is the level of the $\mathrm{k}^{\text {th }}$ input used by the $\mathrm{i}^{\text {th }}$ economy in period $t ; \alpha_{1 i}$ is the intercept term for the $i^{\text {th }}$ economy; $\beta_{k i}$ is the actual response of the output to the method of application of the $\mathrm{k}^{\text {th }}$ input by the $\mathrm{i}^{\text {th }}$ economy; and $u_{k l}$ refers to the random variable term which has mean zero and variance $\sigma_{u k k}$. Let

$$
\beta_{k i}=\bar{\beta}_{k}+u_{k l} ; \quad \mathrm{k}=1,2, \ldots \mathrm{K} \text { and } \mathrm{i}=1,2, \ldots \mathrm{N}
$$

where,

$$
\begin{aligned}
& E\left(\beta_{k \imath}\right)=\bar{\beta}_{k}, \\
& E\left(u_{k \imath}\right)=0 \text { and } \\
& \operatorname{Var}\left(u_{k l}\right)=\sigma_{\imath \jmath k} \text { for } \mathrm{j}=\mathrm{k} \text { and } 0 \text { otherwise. }
\end{aligned}
$$

With these assumptions, model (1) can be written as

$$
\ln Y_{i t}=\bar{\alpha}_{1}+\sum_{k=2}^{K} \bar{\beta}_{k} \ln X_{k t}+w_{k i t}
$$

where

$$
\begin{aligned}
& w_{k t t}=\sum_{k=2}^{K} u_{k t} \ln X_{k t t}+u_{1 u} \\
& E\left(w_{k i t}\right)=0 \text { for all i and } k . \\
& \operatorname{Var}\left(w_{k i t}\right)=\sigma_{u l t}+\sum_{k=2}^{K} \sigma_{u k k} \ln ^{2} X_{k i t} \\
& \operatorname{COV}\left(w_{k i t}, w_{j i t}\right)=0 \text { for } k \neq j .
\end{aligned}
$$


Following the estimation procedures suggested by Hildreth and Houck (1968), the mean response coefficients ( $\bar{\alpha}$ 's) and the variances $\left(\sigma_{u k k}\right)$ can be estimated and the individual response coefficients ( $\beta_{k l}$ 's) can be obtained as described in Griffiths (1972). Drawing on Kalirajan and Obwona (1994), the assumptions underlying model (2) are as follows:

(i) Technical efficiency is achieved by adopting the best practice techniques, which involve the efficient use of inputs. Technical efficiency stems from two sources: (1) the efficient use of each input which contributes individually to technical efficiency and can be measured by the magnitudes of the varying slope coefficients, $\beta_{k i}$ 's; and (2) any other economy-specific intrinsic characteristics which are not explicitly included may produce a combined contribution over and above the individual contributions. This 'lump sum' contribution, if any, can be measured by the varying intercept term.

(ii) The highest magnitude of each response coefficient and the intercept form the production coefficients of the potential frontier production function. Let ( $\alpha^{*}$ 's) and ( $\beta^{*}$ 's) be the estimates of the coefficients of the frontier production function, that is,

$$
\alpha_{k}^{*}=\max _{i}\left\{\alpha_{k l}\right\} ; \beta_{j}^{*}=\max _{l}\left\{\beta_{n l}\right\}, \mathrm{k}=1, \ldots \mathrm{K} ; \mathrm{i}=1, \ldots, \mathrm{N} \text { and } j=2, \ldots, \mathrm{T} \text {. }
$$

Now the potential frontier output for individual observations can be calculated as

$$
\ln Y_{i t}^{*}=\alpha_{1}^{*}+\sum_{k=2}^{K} \beta_{k}^{*} \ln X_{k i t} ; \mathrm{i}=1, \ldots \mathrm{N}
$$

where $X_{k i t}$ is the actual level of the $k^{\text {th }}$ input used by the $i^{\text {th }}$ economy in period t. A measure of technical efficiency denoted by, say, $E$, can be defined as

$$
E_{i t}=\frac{Y_{i t}}{\exp \left(\ln Y_{t}^{*}\right)}
$$

where the numerator refers to the realized output and the denominator shows the potential frontier output calculated from (3).

\section{Decomposition of TFP Growth}

Figure 1, which is in logarithms, illustrates the decomposition of total output growth into input growth, technical progress and technical efficiency improvement. In periods 1 and 2 , the economy faces production frontiers $F_{1}$ and $F_{2}$ respectively. If a given economy has been technically efficient, output would be $y_{1}{ }^{*}$ in period 1 and $y_{2}{ }^{*}$ in period 2. On the other hand, if the economy is technically inefficient and does not operate on its frontier, then the economy's realized output is $y_{1}$ in period 1 and $y_{2}$ in period 2 .

Technical inefficiency is measured by the vertical distance between the frontier output and the realized output of a given firm, that is, TE1 in period 1 and TE2 in period 2 , respectively. Hence, the change in technical efficiency over time is the difference between TE1 and TE2. 
Productivity, Efficiency and Economic Growth 105

Figure 1: Decomposition of Output Growth

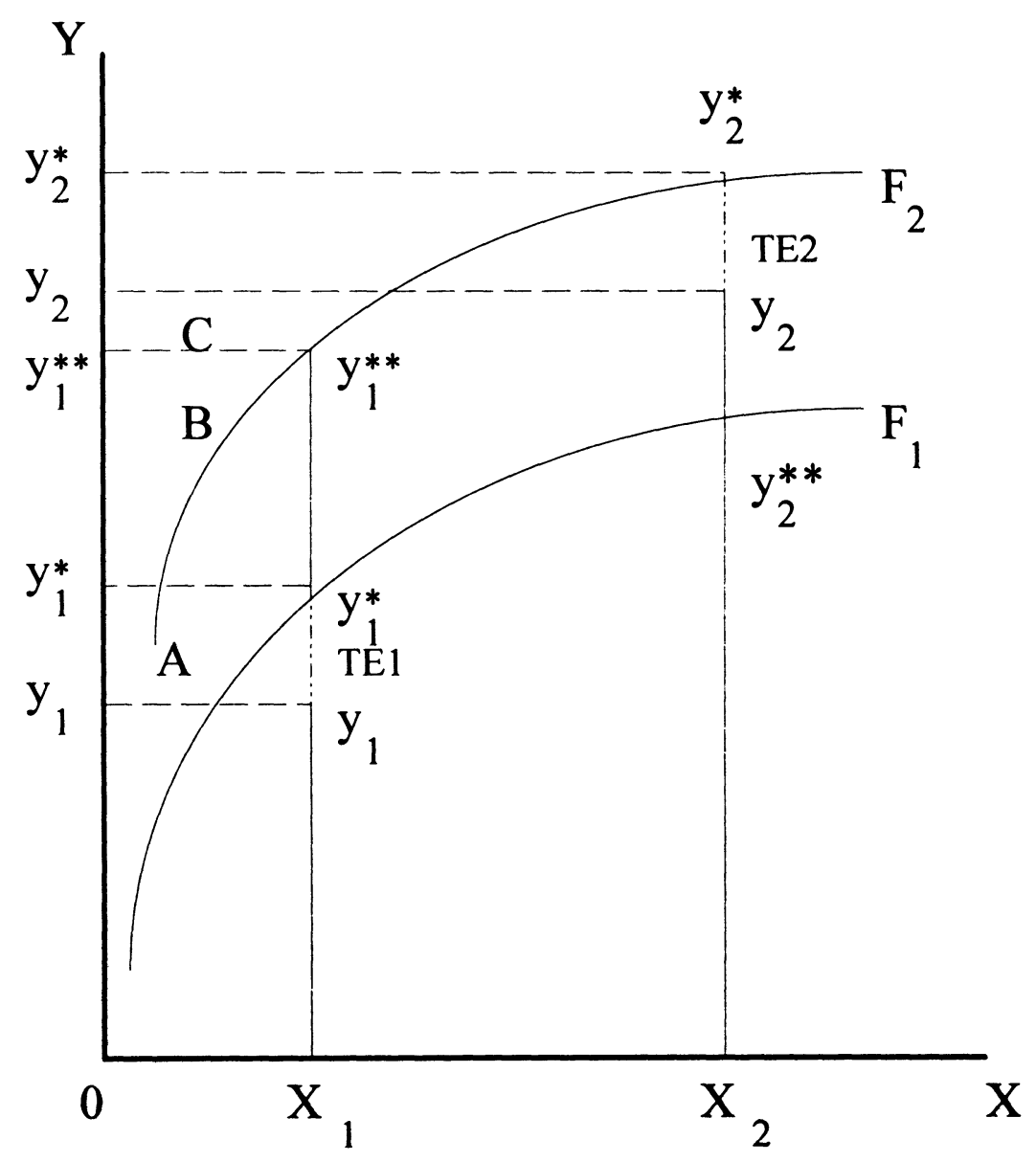




\section{Gaofeng Han, Kaliappa Kalirajan, Nirvikar Singh}

Technological improvement is measured by the distance between frontier $F_{2}$ and frontier $F_{1}$, that is, $\left(y_{2}{ }^{*}-y_{2}{ }^{* *}\right)$ using $x_{2}$ input levels or $\left(y_{1}^{* *}-y_{1}^{*}\right)$ using $x_{1}$ input levels. Denoting the contribution of input growth to output growth (between periods 1 and 2 ) as $\Delta y_{x}$, the total output growth, $\left(y_{2}-y_{1}\right)$, can be decomposed into three components: input growth, technological progress and technical efficiency change.

Referring to Figure 1 , the decomposition can be shown as follows:

$$
\begin{aligned}
& D=y_{2}-y_{1} \\
& =\mathrm{A}+\mathrm{B}+\mathrm{C} \\
& =\left[y_{1}^{*}-y_{1}\right]+\left[y_{1}^{* *}-y_{1}^{*}\right]+\left[y_{2}-y_{1}^{* *}\right] \\
& =\left[y_{1}^{*}-y_{1}\right]+\left[y_{1}^{* *}-y_{1}^{*}\right]+\left[y_{2}-y_{1}^{* *}\right]+\left[y_{2}^{*}-y_{2}^{*}\right] \\
& =\left[y_{1}^{*}-y_{1}\right]+\left[y_{1}^{* *}-y_{1}^{*}\right]-\left[y_{2}^{* *}-y_{2}\right]+\left[y_{2}^{*}-y_{1}^{* *}\right] \\
& =\left\{\left[y_{1}^{*}-y_{1}\right]-\left[y_{2}^{*}-y_{2}\right]\right\}+\left[y_{1}^{* *}-y_{1}^{*}\right]+\left[y_{2}^{*}-y_{1}^{* *}\right] \\
& =\{\mathrm{TE} 1-\mathrm{TE} 2\}+\mathrm{TC}+\Delta y_{x}
\end{aligned}
$$

where,

$$
\begin{aligned}
& y_{2}-y_{1}=\text { Output growth } \\
& \text { TE1 }- \text { TE2 = Technical efficiency change } \\
& \text { TC }=\text { Technical change and } \\
& \Delta y_{x}=\text { Output growth due to input growth. }
\end{aligned}
$$

Solow (1957) attributed output growth to input growth and technical change. The decomposition in (5) enriches Solow's dichotomy by attributing observed output growth to movements along a path on or beneath the production frontier (input growth), movement toward or away from the production frontier (technical efficiency change), and shifts in the production frontier (technolcgical progress).

\section{Data}

The data is from the Penn World Tables and the World Bank STARS database. We choose sample countries based on the data quality ranking by Summers (1992) (see Appendix). Any economy chosen is at least at the three-star level, which leaves a total of 45 economies in our sample. Unfortunately, Hong Kong is not in our sample, but other East Asian high performers are included. The series retrieved from the Penn World tables are capital stock per worker (1985 international prices), real GDP per capita (1985 international prices), and the series from STARS are population and labor force. We multiply capital per worker by labor force to get capital stock, and multiply real GDP per capita by population to get real GDP. The GDP and capital stock are measured in dollars, and labor force is measured in persons. 


\section{EMPIRICAL RESULTS}

Using the methodology described in the previous section, we estimated frontier production functions for the 45 country sample year by year for 1970, 1975, 1980, 1985, and 1990. Given the objective of this paper, we used the frontier production function estimates to calculate the technical efficiency, technical progress and inputs growth for each country by decomposing the growth rates for 1970-1975, 1975-1980, 1980-1985, and $1985-1990$.

Detailed results are presented in the Appendix, while we discuss the overall results in this section. Though we could not test individual country's production function because of the sample property, the mean response coefficients estimates of all countries for the chosen 5 years are tested for individual years for constant returns to scale. Results based on Wald's test statistics indicate that the hypothesis of constant returns to scale could not be rejected for the chosen data set. The results are given in Appendix Table A1.

Table 1 indicates that growth was almost positive in the economies during the periods analyzed here, and that the estimated contribution of input accumulation to growth was also almost invariably positive. The TFP growth was positive slightly less than half the time on average (across all the sub periods). On decomposing the TFP growth, the results show that estimated technical efficiency changes tended to be positive more often than the other component.

Table 2 presents more specific results for the four high performing East Asian economies in our sample: Japan, Singapore, South Korea and Taiwan, as well as averages for the whole sample and for OECD countries in the sample. Japan's TFP growth rates are estimated to be negative or negligible throughout the period. Korea had negative TFP growth in the first decade, switching to positive in the 1980s. Singapore does not show up too badly in terms of TFP growth according to this methodology; it had positive TFP growth during 1970-75 and 1985-90, though its TFP growth was negative during 1975-1985. Finally, Taiwan's TFP growth alternates signs between negative and positive during the period of analysis. Overall, none of the four economies stands out from the others in terms of high TFP growth, and the patterns over time appear to be quite different. This broad conclusion also holds for the estimated components of TFP growth, namely, technical efficiency change (TEC) and technological progress (TP): there is no obvious similarity in patterns over time, and no economy stands out in terms of levels of performance.

Table 1: Positive Signs in Estimated Growth Decompositions

\begin{tabular}{|c|c|c|c|c|c|}
\hline Period & Growth & TEC & TP & TFPG & Inputs \\
\hline $1970-75$ & 44 & 6 & 42 & 14 & 44 \\
\hline $1975-80$ & 43 & 30 & 4 & 26 & 44 \\
\hline $1980-85$ & 40 & 33 & 0 & 14 & 44 \\
\hline $1985-90$ & 42 & 35 & 10 & 34 & 43 \\
\hline
\end{tabular}


Next we turn to comparisons of the four East Asian economies with the OECD and the whole sample averages. With the exception of Japan, which is already a matured economy in the sample period, the other three economies have significantly better growth performances than the averages in each sub period. However, in almost every case, the difference in growth performance compared to the averages is largely, or even wholly, accounted for by a higher input contribution. Thus, in the case of Japan, the result is in conformity with the conclusion of Hayami and Ogasawara that Japan has continued to depend more heavily on physical capital accumulation even since Japan's economy has reached a mature stage and the accumulation of human-capital-augmented labour, which can be gauged by the technical efficiency improvements, was not faster than that physical capital in Japan.

Table 2: Growth Decompositions for East Asian High Performers

\begin{tabular}{|l|c|c|c|c|c|}
\hline & Growth & TEC & TP & TFPG & Inputs \\
\hline 1970-75 & & & & & \\
\hline Japan & 0.21 & -0.27 & 0.06 & -0.21 & 0.42 \\
\hline Korea & 0.42 & -0.11 & 0.02 & -0.09 & 0.51 \\
\hline Singapore & 0.66 & -0.09 & 0.13 & 0.04 & 0.62 \\
\hline Taiwan & 0.43 & -0.19 & 0.07 & -0.12 & 0.55 \\
\hline OECD Average & 0.20 & -0.14 & 0.15 & 0.01 & 0.19 \\
\hline Sample Average & 0.22 & -0.13 & 0.10 & -0.03 & 0.25 \\
\hline 1975-80 & & & & & \\
\hline Japan & 0.23 & 0.03 & -0.03 & 0.00 & 0.23 \\
\hline Korea & 0.36 & -0.02 & -0.01 & -0.03 & 0.39 \\
\hline Singapore & 0.34 & -0.03 & -0.03 & -0.06 & 0.40 \\
\hline Taiwan & 0.48 & 0.03 & -0.02 & 0.01 & 0.47 \\
\hline OECD Average & 0.17 & 0.04 & -0.03 & 0.01 & 0.16 \\
\hline Sample Average & 0.23 & 0.02 & -0.02 & 0.00 & 0.22 \\
\hline 1980-85 & & & & & \\
\hline Japan & 0.19 & 0.13 & -0.15 & -0.02 & 0.21 \\
\hline Korea & 0.38 & 0.27 & -0.16 & 0.11 & 0.27 \\
\hline Singapore & 0.32 & -0.05 & -0.08 & -0.13 & 0.45 \\
\hline Taiwan & 0.28 & 0.03 & -0.13 & -0.10 & 0.38 \\
\hline OECD Average & 0.07 & 0.01 & -0.11 & -0.10 & 0.17 \\
\hline Sample Average & 0.07 & 0.03 & -0.14 & -0.11 & 0.18 \\
\hline 1985-90 & & & & & \\
\hline Japan & 0.22 & -0.01 & 0.01 & 0.00 & 0.22 \\
\hline Korea & 0.51 & 0.13 & 0.00 & 0.14 & 0.37 \\
\hline Singapore & 0.40 & 0.21 & -0.07 & 0.14 & 0.26 \\
\hline Taiwan & 0.45 & 0.18 & -0.03 & 0.14 & 0.30 \\
\hline OECD Average & 0.23 & 0.12 & -0.04 & 0.08 & 0.14 \\
\hline Sample Average & 0.22 & 0.10 & -0.02 & 0.08 & 0.14 \\
\hline & & & & & \\
\hline
\end{tabular}


Input contribution of OECD average is also lower than in the four economies. Whether we compare estimated TFP growth, efficiency changes or technological progress, the East Asian high performers do not appear to stand out compared to the sample overall, or compared to OECD countries. Our conclusion based on these estimates would therefore be in line with Alwyn Young's, though the methodology used is quite different: East Asian growth can be mostly explained by high rates of input accumulation.

Aside from the issue of TFP growth and its decomposition into efficiency change and technological progress, another measure of East Asian growth performance is the calculation of their relative efficiency, and how that changes over time. In Table 3, we present the technical efficiency (catching up with the production frontier) rankings for each of the five years in our data. By fitting a production frontier to each year's data, we are able to estimate where each country in the sample lies relative to the global production frontier involving sample countries. Technical efficiency is defined as the ratio of realized output to potential output.

On the whole, the results on efficiency rankings seem reasonable. The bulk of the high-efficiency group made up of developed economies such as the United States, United Kingdom and Canada are high in the rankings, whereas economies typically perceived as inefficient are much lower down. Of the four high-performing East Asian economies in our sample, only Taiwan appears high in the efficiency rankings. Japan moves around in the middle of the pack over this period, while Singapore and Korea are invariably in the lower third and fourth groups for all the sample years. Thus, the frontier estimations suggest that in general the high performing East Asian economies did not stand out in terms of levels or improvements in technical efficiency compared to the rest of the world, even as they were achieving great strides in development and growth during these years. In other words, during the study period, these East Asian countries had been producing inside the frontier and slightly shifting the frontier without realizing fully the frontier with which they were operating.

\section{CONCLUSION}

In this paper, we use the varying coefficients stochastic production frontier approach and cross-section data for 45 countries to analyze the sources of economic growth in East Asia and compare them with the rest of the world, particularly the OECD countries. Our methodology allows us to decompose the TFP growth into technical efficiency change and technological progress. Further, this methodology facilitated carrying out additional analysis, which was not previously done by Young or other researchers. One such extension of analysis is that of the efficiency ranking and comparison across the countries. Other methodologies might allow for TFP ranking, but not the Technical Efficiency ranking. We can do both, though we have emphasized the latter in our paper. 
110 Gaofeng Han, Kaliappa Kalirajan, Nirvikar Singh

Table 3: Technical Efficiency (catching up)

Ranking Across Economies.

\begin{tabular}{|c|c|c|c|c|}
\hline 1970 & 1975 & 1980 & 1985 & 1990 \\
\hline Argentina & Argentina & Argentina & Australia & Canada \\
\hline Austria & Austria & Australia & Canada & Denmark \\
\hline Denmark & Canada & Austria & Denmark & Ireland \\
\hline Germany & New Zealand & Canada & Morocco & Israel \\
\hline New Zealand & Sweden & Denmark & New Zealand & Morocco \\
\hline Sweden & Taiwan & New Zealand & Sweden & Portugal \\
\hline Taiwan & United Kingdom & Sweden & Taiwan & Taiwan \\
\hline United Kingdom & United States & Taiwan & United Kingdom & United Kingdom \\
\hline United States & Denmark & United Kingdom & United States & United States \\
\hline Venezuela & Venezuela & United States & Argentina & Australia \\
\hline Australia & Australia & Belgium & Austria & Austria \\
\hline Belgium & France & France & France & Belgium \\
\hline Canada & Germany & Germany & Ireland & France \\
\hline Chile & Ireland & Ireland & Israel & Italy \\
\hline Ireland & Israel & Israel & Italy & Jamaica \\
\hline Israel & Jamaica & Italy & Jamaica & Japan \\
\hline Italy & Japan & Japan & Japan & Luxembourg \\
\hline Jamaica & Malaysia & Luxembourg & Malaysia & Malaysia \\
\hline Japan & Mexico & Malaysia & Mexico & Netherlands \\
\hline Luxembourg & Morocco & Mexico & Netherlands & New Zealand \\
\hline Malaysia & Netherlands & Morocco & Norway & Norway \\
\hline Netherlands & Portugal & Netherlands & Portugal & Sweden \\
\hline Spain & Spain & Norway & Thailand & Thailand \\
\hline Switzerland & Belgium & Portugal & Belgium & Argentina \\
\hline Bolivia & Chile & Chile & Chile & Chile \\
\hline Finland & Finland & Finland & Finland & Finland \\
\hline Greece & Greece & Greece & Germany & Germany \\
\hline Korea & Italy & Jamaica & India & Greece \\
\hline Mexico & Luxembourg & Peru & Korea & India \\
\hline Morocco & Norway & Philippines & Luxembourg & Korea \\
\hline Norway & Peru & Singapore & Singapore & Mexico \\
\hline Panama & Philippines & Spain & Spain & Philippines \\
\hline Peru & Singapore & Switzerland & Switzerland & Singapore \\
\hline Philippines & Switzerland & Thailand & Turkey & Spain \\
\hline Portugal & Thailand & Turkey & Venezuela & Switzerland \\
\hline Singapore & Turkey & Venezuela & Bolivia & Turkey \\
\hline Thailand & Bolivia & Bolivia & Colombia & Venezuela \\
\hline Turkey & Colombia & Colombia & Ecuador & Bolivia \\
\hline Colombia & Ecuador & Ecuador & Greece & Colombia \\
\hline Ecuador & Honduras & Honduras & Honduras & Ecuador \\
\hline France & India & India & Panama & Honduras \\
\hline Honduras & Korea & Korea & Peru & Panama \\
\hline India & Panama & Panama & Philippines & Peru \\
\hline Sri Lanka & Sri Lanka & Sri Lanka & Sri Lanka & Sri Lanka \\
\hline Zimbabwe & Zimbabwe & Zimbabwe & Zimbabwe & Zimbabwe \\
\hline
\end{tabular}


Our findings elaborate on the status of the components of TFP. Technical efficiency rankings need not be consistent with TFP rankings. For example, (a) Taiwan has a much higher rank in terms of technical efficiency, compared to the TFP rank; (b) Industrialized economies, such as US, UK, Canada, New Zealand, Sweden, Austria, Australia, are well on the top of the efficiency ranking, while in Young (94), they are at mediocre or low level in terms of the TFP ranking. The difference of these two rankings indeed gives our methodology some leverage. For those industrialized countries, even TFP is low at certain period of time, they stand out by their high technical efficiency, which is one of the important criterions for sustaining a country's competitiveness globally. Thus, our analysis adds another valuable dimension in sources of growth analysis.

Our estimation results suggest that during 1970-1990, the four high-performing East Asian economies in our sample - Japan, Singapore, South Korea and Taiwan - do not stand out from the rest of the world in terms of their TFP growth performance, or in terms of their efficiency in input use. Input growth appears to be the main contributor to their overall economic growth. It may be argued that institutions have been playing important roles in fostering such a pattern of growth in East Asia. In the context of the labour input, these Asian economies have large populations and so it is natural that their usage of labor input is large compared to the Western countries. In the context of capital input, Asian economies have high savings, which is exactly related to Asian Culture. People work and save much, which is obviously opposite to Western countries. The high savings finally have to be transformed into high investment. Besides, Governments in these countries tend to keep high employment, which is also related to Policy as well as Asian Culture. The culture makes layoffs more difficult than in other regions. In addition, there are no unemployment benefits as is the case in Western countries.

Considering the policy implications, it is clear from Table 3 that East Asian countries appear to have a lot of catching up to do in technical efficiency improvements. Why do Japan, Korea and Singapore have mediocre or low Tech efficiency? Japanese, Korean and Singaporean firms are well guided or backed by their governments during development. They are not as flexible as US firms with respect to human resources policy and investment policy. Korea's Chaebol and Japan's Harachu are typical institutions (structure) that could lead to high efficiency as well as low efficiency. The low efficiency emerges if: [a] employees feel that they have lifetime employment (as in China) so they will shirk; [2] rigid firm structure could not respond to the varying goods demand outside. Korea had, and Japan still has, such problems once world demand of goods declined. Over capacity and lack of quick adjustment policy such as in the US could tie down efficiency easily. It is not surprising that most of the firms in these economies 


\section{Gaofeng Han, Kaliappa Kalirajan, Nirvikar Singh}

have mediocre technical efficiency. As for Singapore, low technical efficiency might be the result of vast new technical introductions from abroad during the period, but knowledge and experience did not match the requirements of new technologies. Recently Singapore brought many educated employees from countries like China and India to improve their human capital.

And finally, why does Taiwan have high technical efficiency? Taiwan also has government guidance like other East Asian economies. However, Taiwanese firms are more flexible than in other economies. It has no firm structure such as Chaebol and Harachu, this might contribute to its relatively high technical efficiency. Efficiency is dynamically changing, rather than being static. What we see from table 2 , is that, the efficiency improvement had lead to a big TFP growth for most of the East Asian economies during 1985-1990. In closing, culture, institutions, and policies appear to shape development as well as improve efficiency in East Asia.

\section{APPENDIX}

Table A1: Results of Testing of Constant Returns to Scale

\begin{tabular}{|c|c|c|c|c|c|}
\hline & 1970 & 1975 & 1980 & 1985 & 1990 \\
\hline $\mathrm{B}_{1}$ & $5.39 \mathrm{E}-01$ & $6.26 \mathrm{E}-01$ & $6.06 \mathrm{E}-01$ & $6.61 \mathrm{E}-01$ & $6.38 \mathrm{E}-01$ \\
\hline $\mathrm{B}_{2}$ & $4.77 \mathrm{E}-01$ & $3.79 \mathrm{E}-01$ & $3.97 \mathrm{E}-01$ & $3.32 \mathrm{E}-01$ & $3.72 \mathrm{E}-01$ \\
\hline $\mathrm{SE}\left(\beta_{1}\right)$ & $3.70 \mathrm{E}-02$ & $5.87 \mathrm{E}-02$ & $7.67 \mathrm{E}-02$ & $4.99 \mathrm{E}-02$ & $5.55 \mathrm{E}-02$ \\
\hline $\mathrm{SE}\left(\beta_{2}\right)$ & $4.46 \mathrm{E}-02$ & $6.72 \mathrm{E}-02$ & $8.63 \mathrm{E}-02$ & $5.63 \mathrm{E}-02$ & $6.42 \mathrm{E}-02$ \\
\hline Chi sqr $(1)$ & $7.46 \mathrm{E}-02$ & $2.85 \mathrm{E}-03$ & $7.74 \mathrm{E}-04$ & $8.49 \mathrm{E}-03$ & $1.20 \mathrm{E}-02$ \\
\hline $5 \%$ critical value & $3.84 \mathrm{E}+00$ & $3.84 \mathrm{E}+00$ & $3.84 \mathrm{E}+00$ & $3.84 \mathrm{E}+00$ & $3.84 \mathrm{E}+00$ \\
\hline Result & Accept $\mathrm{H}_{0}$ & Accept $\mathrm{H}_{0}$ & Accept $\mathrm{H}_{0}$ & Accept $\mathrm{H}_{0}$ & Accept $\mathrm{H}_{0}$ \\
\hline
\end{tabular}

Note: $\mathrm{H}_{0}$ : constant returns to scale 
Productivity, Efficiency and Economic Growth 113

Table A2: Country Based Growth Decomposition, 1970-1975

\begin{tabular}{|c|c|c|c|c|c|}
\hline Country & Growth & TEC & TP & TFPG & Inputs \\
\hline Argentina & 0.15 & -0.18 & 0.07 & -0.10 & 0.26 \\
\hline Australia & 0.17 & -0.21 & 0.18 & -0.02 & 0.20 \\
\hline Austria & 0.19 & -0.23 & 0.15 & -0.08 & 0.27 \\
\hline Belgium & 0.16 & -0.20 & 0.18 & -0.03 & 0.19 \\
\hline Bolivia & 0.22 & -0.22 & 0.07 & -0.14 & 0.37 \\
\hline Canada & 0.26 & -0.10 & 0.17 & 0.07 & 0.19 \\
\hline Chile & -0.10 & -0.37 & 0.09 & -0.28 & 0.18 \\
\hline Colombia & 0.26 & -0.13 & 0.09 & -0.04 & 0.30 \\
\hline Denmark & 0.08 & -0.28 & 0.18 & -0.10 & 0.18 \\
\hline Ecuador & 0.55 & 0.10 & 0.11 & 0.21 & 0.34 \\
\hline Finland & 0.19 & -0.22 & 0.19 & -0.03 & 0.22 \\
\hline France & 0.15 & 1.10 & 0.30 & 1.40 & -1.25 \\
\hline Germany & 0.08 & -0.44 & 0.14 & -0.30 & 0.38 \\
\hline Greece & 0.24 & -0.19 & 0.13 & -0.07 & 0.30 \\
\hline Honduras & 0.19 & -0.10 & 0.08 & -0.02 & 0.20 \\
\hline India & 0.13 & 0.01 & -0.14 & -0.13 & 0.26 \\
\hline Ireland & 0.22 & -0.21 & 0.15 & -0.06 & 0.28 \\
\hline Israel & 0.37 & -0.14 & 0.18 & 0.04 & 0.33 \\
\hline Italy & 0.12 & -0.20 & 0.12 & -0.08 & 0.20 \\
\hline Jamaica & 0.17 & -0.13 & 0.11 & -0.02 & 0.19 \\
\hline Japan & 0.21 & -0.27 & 0.06 & -0.21 & 0.42 \\
\hline Korea & 0.42 & -0.11 & 0.02 & -0.09 & 0.51 \\
\hline Luxembourg & 0.15 & -0.27 & 0.28 & 0.01 & 0.14 \\
\hline Malaysia & 0.33 & -0.11 & 0.03 & -0.08 & 0.42 \\
\hline Mexico & 0.37 & -0.04 & 0.08 & 0.04 & 0.33 \\
\hline Morocco & 0.27 & 0.06 & -0.02 & 0.04 & 0.23 \\
\hline Netherlands & 0.16 & -0.23 & 0.17 & -0.06 & 0.22 \\
\hline New Zealand & 0.20 & -0.23 & 0.21 & -0.02 & 0.23 \\
\hline Norway & 0.23 & -0.05 & 0.24 & 0.19 & 0.04 \\
\hline Panama & 0.24 & -0.35 & 0.16 & -0.19 & 0.43 \\
\hline Peru & 0.28 & -0.02 & 0.10 & 0.08 & 0.20 \\
\hline Philippines & 0.29 & 0.07 & 0.01 & 0.08 & 0.21 \\
\hline Portugal & 0.27 & -0.07 & 0.07 & 0.00 & 0.27 \\
\hline Singapore & 0.66 & -0.09 & 0.13 & 0.04 & 0.62 \\
\hline Spain & 0.26 & -0.16 & 0.09 & -0.07 & 0.33 \\
\hline Sri Lanka & 0.11 & -0.15 & 0.08 & -0.07 & 0.18 \\
\hline Sweden & 0.12 & -0.19 & 0.18 & -0.01 & 0.13 \\
\hline Switzerland & 0.03 & -0.40 & 0.23 & -0.17 & 0.19 \\
\hline Taiwan & 0.43 & -0.19 & 0.07 & -0.12 & 0.55 \\
\hline Thailand & 0.24 & -0.09 & -0.04 & -0.12 & 0.37 \\
\hline Turkey & 0.38 & 0.00 & 0.01 & 0.01 & 0.37 \\
\hline United Kingdom & 0.10 & -0.15 & 0.09 & -0.06 & 0.15 \\
\hline United States & 0.11 & -0.18 & 0.12 & -0.06 & 0.17 \\
\hline Venezuela & 0.13 & -0.27 & 0.16 & -0.11 & 0.24 \\
\hline Zimbabwe & 0.37 & -0.02 & 0.09 & 0.08 & 0.29 \\
\hline
\end{tabular}


114 Gaofeng Han, Kaliappa Kalirajan, Nirvikar Singh

Table A3: Country-based Growth Decomposition, 1975-1980

\begin{tabular}{lccccc}
\hline Country & Growth & TEC & TP & TFPG & Inputs \\
\hline Argentina & 0.15 & -0.02 & -0.02 & -0.04 & 0.19 \\
Australia & 0.14 & 0.04 & -0.04 & 0.01 & 0.13 \\
Austria & 0.16 & -0.01 & -0.03 & -0.04 & 0.20 \\
Belgium & 0.15 & 0.06 & -0.04 & 0.02 & 0.13 \\
Bolivia & 0.21 & -0.08 & -0.01 & -0.09 & 0.30 \\
Canada & 0.20 & 0.06 & -0.04 & 0.02 & 0.17 \\
Chile & 0.34 & 0.21 & -0.01 & 0.20 & 0.14 \\
Colombia & 0.27 & 0.07 & -0.02 & 0.05 & 0.22 \\
Denmark & 0.11 & 0.04 & -0.04 & 0.00 & 0.11 \\
Ecuador & 0.34 & -0.04 & -0.02 & -0.06 & 0.40 \\
Finland & 0.14 & 0.06 & -0.04 & 0.02 & 0.11 \\
France & 0.15 & 0.04 & -0.03 & 0.00 & 0.15 \\
Germany & 0.16 & 0.06 & -0.04 & 0.02 & 0.14 \\
Greece & 0.19 & 0.03 & -0.03 & 0.00 & 0.19 \\
Honduras & 0.35 & 0.02 & -0.01 & 0.01 & 0.33 \\
India & 0.19 & -0.08 & 0.02 & -0.06 & 0.25 \\
Ireland & 0.23 & 0.02 & -0.03 & 0.00 & 0.23 \\
Israel & 0.17 & 0.05 & -0.03 & 0.02 & 0.15 \\
Italy & 0.24 & 0.13 & -0.03 & 0.10 & 0.14 \\
Jamaica & -0.15 & -0.18 & -0.01 & -0.19 & 0.04 \\
Japan & 0.23 & 0.03 & -0.03 & 0.00 & 0.23 \\
Korea & 0.36 & -0.02 & -0.01 & -0.03 & 0.39 \\
Luxembourg & 0.12 & 0.08 & -0.04 & 0.04 & 0.08 \\
Malaysia & 0.47 & 0.09 & -0.01 & 0.08 & 0.39 \\
Mexico & 0.33 & 0.07 & -0.02 & 0.04 & 0.29 \\
Morocco & 0.34 & -0.07 & 0.01 & -0.06 & 0.40 \\
Netherlands & 0.13 & 0.01 & -0.04 & -0.02 & 0.15 \\
New Zealand & -0.01 & 0.21 & -0.04 & 0.17 & -0.18 \\
Norway & 0.24 & 0.22 & -0.04 & 0.17 & 0.07 \\
Panama & 0.27 & 0.05 & -0.03 & 0.03 & 0.25 \\
Peru & 0.04 & -0.13 & -0.02 & -0.15 & 0.18 \\
Philippines & 0.26 & 0.05 & 0.00 & 0.05 & 0.21 \\
Portugal & 0.22 & 0.10 & -0.02 & 0.09 & 0.13 \\
Singapore & 0.34 & -0.03 & -0.03 & -0.06 & 0.40 \\
Spain & 0.07 & -0.11 & -0.03 & -0.14 & 0.21 \\
Sri Lanka & 0.33 & 0.12 & -0.01 & 0.10 & 0.23 \\
Sweden & 0.05 & 0.01 & -0.04 & -0.03 & 0.08 \\
Switzerland & 0.08 & 0.04 & -0.05 & -0.01 & 0.09 \\
Taiwan & 0.48 & 0.03 & -0.02 & 0.01 & 0.47 \\
Thailand & 0.38 & -0.05 & 0.01 & -0.05 & 0.42 \\
Turkey & 0.12 & -0.21 & -0.01 & -0.22 & 0.33 \\
United Kingdom & 0.09 & 0.01 & -0.03 & -0.01 & 0.10 \\
United States & 0.16 & 0.08 & -0.03 & 0.05 & 0.12 \\
Venezuela & 0.17 & -0.18 & -0.03 & -0.21 & 0.38 \\
Zimbabwe & 0.03 & -0.07 & -0.01 & -0.08 & 0.11 \\
\hline & & & & & \\
\hline
\end{tabular}


Productivity, Efficiency and Economic Growth 115

Table A4: Country-based Growth Decomposition, 1980-1985

\begin{tabular}{|c|c|c|c|c|c|}
\hline Country & Growth & TEC & TP & TFPG & Inputs \\
\hline Argentina & -0.13 & -0.06 & -0.15 & -0.21 & 0.08 \\
\hline Australia & 0.15 & 0.10 & -0.09 & 0.00 & 0.15 \\
\hline Austria & 0.06 & -0.01 & -0.09 & -0.10 & 0.16 \\
\hline Belgium & 0.02 & 0.03 & -0.09 & -0.05 & 0.07 \\
\hline Bolivia & 0.00 & 0.08 & -0.14 & -0.05 & 0.06 \\
\hline Canada & 0.14 & 0.08 & -0.11 & -0.03 & 0.17 \\
\hline Chile & -0.03 & 0.01 & -0.16 & -0.15 & 0.12 \\
\hline Colombia & 0.11 & 0.05 & -0.15 & -0.10 & 0.21 \\
\hline Denmark & 0.13 & 0.16 & -0.08 & 0.08 & 0.05 \\
\hline Ecuador & 0.02 & -0.09 & -0.12 & -0.21 & 0.23 \\
\hline Finland & 0.13 & 0.07 & -0.07 & 0.00 & 0.13 \\
\hline France & 0.06 & 0.06 & -0.12 & -0.06 & 0.12 \\
\hline Germany & 0.04 & -0.20 & -0.10 & -0.30 & 0.34 \\
\hline Greece & -1.12 & -1.14 & -0.11 & -1.25 & 0.13 \\
\hline Honduras & 0.09 & 0.19 & -0.14 & 0.04 & 0.04 \\
\hline India & 0.28 & 0.38 & -0.30 & 0.08 & 0.20 \\
\hline Ireland & 0.10 & 0.02 & -0.09 & -0.07 & 0.17 \\
\hline Israel & 0.14 & 0.10 & -0.08 & 0.02 & 0.12 \\
\hline Italy & 0.06 & 0.05 & -0.13 & -0.07 & 0.13 \\
\hline Jamaica & 0.02 & 0.20 & -0.15 & 0.05 & -0.03 \\
\hline Japan & 0.19 & 0.13 & -0.15 & -0.02 & 0.21 \\
\hline Korea & 0.38 & 0.27 & -0.16 & 0.11 & 0.27 \\
\hline Luxembourg & 0.11 & -0.01 & -0.02 & -0.03 & 0.14 \\
\hline Malaysia & 0.22 & -0.03 & -0.17 & -0.20 & 0.42 \\
\hline Mexico & 0.03 & 0.02 & -0.16 & -0.13 & 0.17 \\
\hline Morocco & 0.14 & 0.16 & -0.21 & -0.05 & 0.19 \\
\hline Netherlands & 0.05 & 0.07 & -0.10 & -0.03 & 0.07 \\
\hline New Zealand & 0.15 & -0.19 & -0.09 & -0.28 & 0.44 \\
\hline Norway & 0.17 & 0.14 & -0.06 & 0.08 & 0.09 \\
\hline Panama & 0.14 & 0.04 & -0.09 & -0.04 & 0.18 \\
\hline Peru & 0.00 & -0.04 & -0.15 & -0.19 & 0.19 \\
\hline Philippines & -0.07 & -0.05 & -0.21 & -0.27 & 0.19 \\
\hline Portugal & 0.06 & 0.06 & -0.15 & -0.09 & 0.15 \\
\hline Singapore & 0.32 & -0.05 & -0.08 & -0.13 & 0.45 \\
\hline Spain & 0.05 & 0.04 & -0.13 & -0.09 & 0.14 \\
\hline Sri Lanka & 0.30 & 0.28 & -0.16 & 0.12 & 0.17 \\
\hline Sweden & 0.08 & 0.10 & -0.09 & 0.01 & 0.07 \\
\hline Switzerland & 0.06 & 0.00 & -0.05 & -0.05 & 0.11 \\
\hline Taiwan & 0.28 & 0.03 & -0.13 & -0.10 & 0.38 \\
\hline Thailand & 0.22 & 0.15 & -0.22 & -0.07 & 0.29 \\
\hline Turkey & 0.19 & 0.15 & -0.19 & -0.03 & 0.22 \\
\hline United Kingdom & 0.11 & 0.18 & -0.15 & 0.03 & 0.07 \\
\hline United States & 0.13 & 0.17 & -0.15 & 0.02 & 0.11 \\
\hline Venezuela & -0.03 & -0.05 & -0.11 & -0.15 & 0.12 \\
\hline Zimbabwe & 0.19 & 0.20 & -0.15 & 0.04 & 0.15 \\
\hline
\end{tabular}


116 Gaofeng Han, Kaliappa Kalirajan, Nirvikar Singh

Table A5: Country-based Growth Decomposition, 1985-1990

\begin{tabular}{|c|c|c|c|c|c|}
\hline Country & Growth & TEC & TP & TFPG & Inputs \\
\hline Argentina & -0.06 & -0.08 & -0.01 & -0.08 & 0.02 \\
\hline Australia & 0.14 & 0.01 & -0.04 & -0.03 & 0.17 \\
\hline Austria & 0.15 & 0.08 & -0.05 & 0.03 & 0.12 \\
\hline Belgium & 0.17 & 0.14 & -0.05 & 0.10 & 0.07 \\
\hline Bolivia & 0.07 & 0.08 & -0.03 & 0.05 & 0.02 \\
\hline Canada & 0.15 & -0.01 & -0.03 & -0.04 & 0.19 \\
\hline Chile & 0.31 & 0.02 & -0.01 & 0.01 & 0.30 \\
\hline Colombia & 0.20 & 0.08 & -0.01 & 0.07 & 0.13 \\
\hline Denmark & 0.08 & 0.03 & -0.06 & -0.03 & 0.11 \\
\hline Ecuador & 0.06 & -0.08 & -0.04 & -0.12 & 0.17 \\
\hline Finland & 0.17 & 0.12 & -0.06 & 0.05 & 0.12 \\
\hline France & 0.15 & 0.06 & -0.01 & 0.05 & 0.10 \\
\hline Germany & 0.16 & 0.12 & -0.01 & 0.11 & 0.05 \\
\hline Greece & 1.30 & 1.27 & -0.04 & 1.23 & 0.07 \\
\hline Honduras & 0.15 & 0.04 & -0.03 & 0.01 & 0.13 \\
\hline India & 0.29 & -0.01 & 0.10 & 0.09 & 0.20 \\
\hline Ireland & 0.23 & 0.24 & -0.06 & 0.18 & 0.05 \\
\hline Israel & 0.21 & 0.17 & -0.06 & 0.11 & 0.09 \\
\hline Italy & 0.15 & 0.06 & -0.01 & 0.05 & 0.10 \\
\hline Jamaica & 0.18 & 0.17 & -0.04 & 0.13 & 0.05 \\
\hline Japan & 0.22 & -0.01 & 0.01 & 0.00 & 0.22 \\
\hline Korea & 0.51 & 0.13 & 0.00 & 0.14 & 0.37 \\
\hline Luxembourg & 0.24 & 0.20 & -0.12 & 0.08 & 0.16 \\
\hline Malaysia & 0.34 & 0.11 & -0.02 & 0.09 & 0.25 \\
\hline Mexico & 0.13 & 0.02 & 0.01 & 0.02 & 0.10 \\
\hline Morocco & 0.22 & 0.28 & 0.01 & 0.29 & -0.07 \\
\hline Netherlands & 0.15 & 0.09 & -0.04 & 0.05 & 0.10 \\
\hline New Zealand & 0.04 & 0.00 & -0.07 & -0.07 & 0.11 \\
\hline Norway & 0.07 & 0.07 & -0.07 & 0.00 & 0.08 \\
\hline Panama & -0.09 & -0.10 & -0.07 & -0.17 & 0.08 \\
\hline Peru & -0.05 & -0.13 & -0.01 & -0.15 & 0.10 \\
\hline Philippines & 0.25 & 0.15 & 0.02 & 0.17 & 0.08 \\
\hline Portugal & 0.41 & 0.24 & -0.02 & 0.21 & 0.19 \\
\hline Singapore & 0.40 & 0.21 & -0.07 & 0.14 & 0.26 \\
\hline Spain & 0.25 & 0.07 & -0.01 & 0.06 & 0.19 \\
\hline Sri Lanka & 0.10 & -0.05 & -0.01 & -0.06 & 0.15 \\
\hline Sweden & 0.12 & -0.01 & -0.05 & -0.06 & 0.18 \\
\hline Switzerland & 0.14 & 0.07 & -0.07 & 0.00 & 0.14 \\
\hline Taiwan & 0.45 & 0.18 & -0.03 & 0.14 & 0.30 \\
\hline Thailand & 0.45 & 0.16 & 0.03 & 0.19 & 0.26 \\
\hline Turkey & 0.30 & 0.10 & 0.01 & 0.11 & 0.19 \\
\hline United Kingdom & 0.18 & 0.04 & 0.00 & 0.04 & 0.13 \\
\hline United States & 0.13 & -0.03 & 0.02 & -0.01 & 0.14 \\
\hline Venezuela & 0.10 & 0.05 & -0.03 & 0.02 & 0.08 \\
\hline Zimbabwe & 0.13 & 0.22 & -0.02 & 0.20 & -0.07 \\
\hline
\end{tabular}




\section{REFERENCES}

$\rightarrow$ Aigner, D.J., C.A.K. Lovell, and P. Schmidt (1977), "Formulation and estimation of stochastic frontier production function models", Journal of Econometrics, 6 , 21-37. McGraw-Hill.

Barro, R. and X. Sala-I-Martin (1995), Economic growth. New York:

Barro, R. (1997), Determinants of economic growth: a cross-country empirical study. Cambridge, Mass. : The MIT Press.

Collins, S. and B. Bosworth (1997), 'Economic Growth in East Asia: Accumulation versus Assimilation,' in W.C. Brainard and G.L. Perry, eds. Brookings Papers in Economic Activity, 2, Washington DC: Brookings Institution.

Felipe, J. (1999), "Total Factor Productivity Growth in East Asia: A Critical Survey," Journal of Development Studies, v 35 n 4, 1-41.

$\rightarrow$ Fischer, S. (1993), "The Role of Macroeconomic Factors in Growth," Journal of Monetary Economics, 32, 485-512.

Fried, H., C.A.K. Lovell and S. Schmidt (1993), The measurement of productive efficiency, Oxford University Press.

$\rightarrow$ Griffiths, W. E. (1972), "Estimating actual response coefficients in the HildrethHouck random coefficient model", Journal of the American Statistical Association, 67, 633-35.

Han, G., K.P. Kalirajan and N. Singh (2001), 'Productivity and Economic Growth in East Asia: Innovation, Efficiency and Accumulation', Santa Cruz Center for International Economics Working Paper \#01-20, http://sccie.ucsc.edu/workingpapers/index.html.

Hayami. Y. and J. Ogasawara (1999), "Changes in the Sources of Modern Economic Growth: Japan Compared with the United States", Journal of the Japanese and International Economies, 13, 1-21.

$\rightarrow$ Hildreth, C. and J.P. Houck (1968), "Some estimators for a linear model with random coefficients", Journal of the American Statistical Association, 63, 584-95.

Hughes, H. (1995), "Why have East Asia countries led economic development", Economic Record, 71(212), 88-104.

Kalirajan, K.P. and M.B. Obwona (1994), "Frontier Production Function: The Stochastic Coefficients Approach", Oxford Bulletin of Economics and Statistics, 56, 8796.

$\rightarrow$ Kalirajan, K.P., M.B. Obwona and S. Zhao (1996), “A Decomposition of Total Factor Productivity Growth: The Case of Chinese Agricultural Growth Before and After Reforms", American Journal of Agricultural Economics 78, 331-38.

Kim, Jong-II and L. Lau (1994), "The sources of economic growth in the East Asian newly industrialized countries", Journal of the Japanese and International Economies, 8(3), 235-271.

Krugman, Paul (1994), "The myth of Asia's miracle", Foreign Affairs, November/December. 


\section{Gaofeng Han, Kaliappa Kalirajan, Nirvikar Singh}

Mahadevan, R., and K.P. Kalirajan, 'Singapore's Manufacturing Sector's TFP Growth: A Decomposition Analysis', Journal of Comparative Economics, 2000, vol.28: 828-839.

Marti, C., (1996), "Is There an East Asian Miracle?" Union Bank of Switzerland Economic Research Working Paper, October.

$\rightarrow$ Meeusen, W. and J. van den Broeck (1977), "Efficiency estimation from CobbDouglas production functions with composed error", International Economic Review, 18, 435-44.

Singh, N. and H. Trieu (1999), "Accounting for East Asian Growth: Japan, Korea and Taiwan", Indian Economic Review.

Singh, N. and H. Trieu (1997), "The role of R\&D in explaining total factor productivity growth in Japan, Korea and Taiwan", UCSC Dept. of Economics Working Paper.

$\rightarrow$ Solow, R.M. (1957), "Technical change and the aggregate production", Review of Economics and Statistics, 39(3), 312-20.

Sonobe, T. and K. Otsuka (2001), "A New Decomposition Approach to Growth Accounting: Derivation of the Formula and its Application to Prewar Japan", Japan and the World Economy, 13, 1-14.

Summers, R. and A. Heston (1991), "The Penn World Table (Mark 5): an expanded set of international comparisons, 1950-1987", Quarterly Journal of Economics, 106(2), 1-41.

World Bank (1993), The East Asian Miracle, a World Bank policy research report, Oxford University Press.

Young, A. (1992), "A tale of two cities: factor accumulation and technical change in Hong Kong and Singapore", NBER Macroeconomic Annual, NRT Press.

Young, A. (1994), "Lessons from the East Asian NICs: a contrarian view", European Economic Review, 110(3), 641-680.

$\rightarrow$ Young, A. (1995), "The tyranny of numbers: confronting the statistical realities of the East Asian growth experience", Quarterly Journal of Economics, 110(3), 641-680. 